
cited.

\title{
LEGAL STANDING SERIKAT PEKERJA DALAM MENGAJUKAN GUGATAN PADA PENGADILAN HUBUNGAN INDUSTRIAL (STUDI KASUS : PELANGGARAN HAK CIPTA ATAS NAMA DAN LOGO SERIKAT PEKERJA PADA PUTUSAN NOMOR 7/G/2017/PHI.JMB JUNCTO PUTUSAN MAHKAMAH AGUNG NOMOR 959 K/PDT.SUS- PHI/2017)
}

\author{
Andari Yurikosari \\ (Dosen Fakultas Hukum Universitas Tarumanagara. Meraih Sarjana Hukum pada Fakultas Hukum \\ Universitas Indonesia, Magister Hukum pada Fakultas Hukum Universitas Indonesia, Doktor (Dr.) \\ pada Fakultas Hukum Universitas Indonesia) \\ (E-mail: andari.yurikosari@gmail.com) \\ Karina Hosea \\ (Mahasiswa Program S1 Fakultas Hukum Universitas Tarumanagara)
}

Received: 22 April 2019; Accepted: 29 Mei 2019; Published: 10 Juni 2019

\begin{abstract}
Based on Article 87 of UU Number 2 of 2004 concerning Settlement of Industrial Relations Disputes and Article 25, 1 Letter b concerning Labor Unions, labor unions as legal counsel have the right to represent their members in the Industrial Relations Court. However, in practice, Industrial Court Judges and Supreme Court Judges (Decision Number 7/G/2017/PHI.Jmb and Decision of the Supreme Court Number 959 K/Pdt.Sus-PHI/2017) decide that the legal counsel of LBH KSBSI has no legal standing to represent workers at PT. Petaling Mandra Guna with the consideration that the legal counsel of LBH KSBSI has violated the copyright of name and logo (Decision Number 378-K/Pdt.SusPHI/2017). So that raises problems, how is the position of the union as a legal counsel related to the legal standing and the legal efforts of the LBH KSBSI? From these problems, the authors examined the normative research method. The results of the study show that the Industrial Relations Court is not authorized to decide on cases of industrial disputes based on copyright infringement on the name and logo, because the problem is not its authority and competence. Regulations regarding restrictions on legal remedies are regulated in SEMA which do not include the type and hierarchy of legislation. It is better, LBH KSBSI immediately submit a legal action in the form of a new lawsuit, so as to obtain legal certainty and the legislature immediately includes provisions for limiting legal remedies at SEMA to UU No. 2 of 2004 concerning Settlement of Industrial Relations Disputes.
\end{abstract}

Keywords: Legal Standing, Labor Unions, Industrial Relations Court, Legal Efforts. 


\section{PENDAHULUAN}

\section{A. Latar Belakang}

Negara Indonesia adalah negara yang secara konstitusional menjamin hak atas pekerjaan dan penghidupan yang layak bagi tiap warganya sebagaimana termaktub dalam Pasal 27 ayat (2) Undang-Undang Dasar Negara Republik Indonesia Tahun 1945 (yang selanjutnya disebut dengan UUD NRI 1945). Sebagai implementasi dari Pasal 28 UUD NRI 1945 tentang Kebebasan Berserikat dan Berkumpul, Pemerintah Indonesia telah meratifikasi Konvensi Organisasi Perburuhan Internasional (ILO) Nomor 98 dengan UndangUndang Nomor 18 Tahun 1956 tentang Dasar-Dasar Hak Berorganisasi dan Berunding Bersama. ${ }^{1}$ ) Ratifikasi ini memprakarsai diundangkannya UndangUndang Nomor 21 Tahun 2000 tentang Serikat Pekerja/Serikat Buruh yang memberikan perlindungan hukum bagi para pekerja untuk mendirikan organisasi baik di perusahaan maupun diluar perusahaan, yang bersifat bebas,

1 ) Lalu Husni, Hukum Ketenagakerjaan Indonesia, Cetakan ke-4 (Jakarta: Raja Grafindo Persada, 2003), hal. 2. terbuka, mandiri, demokratis, dan bertanggungjawab guna memperjuangkan, membela, serta melindungi hak dan kepentingan pekerja serta meningkatkan kesejahteraan pekerja dan keluarganya.

Keberadaan serikat pekerja bertujuan untuk memberikan perlindungan, pembelaan hak dan kepentingan memiliki peran untuk menyelesaikan perselisihan melalui Pengadilan Hubungan Industrial sebagaimana tercantum pada Pasal 87 Undang-Undang Nomor 2 Tahun 2004 tentang Penyelesaian Perselisihan Hubungan Industrial (PPHI). Disebutkan bahwa serikat pekerja dapat bertindak sebagai kuasa hukum untuk beracara di Pengadilan Hubungan Industrial untuk mewakili anggotanya. Selanjutnya, pada Pasal 25 ayat (1) huruf b UndangUndang Nomor 21 Tahun 2000 tentang Serikat Pekerja/Serikat Buruh diatur lebih lanjut mengenai serikat pekerja, federasi dan konfederasi serikat pekerja yang telah mempunyai nomor bukti pencatatan berhak mewakili pekerja dalam menyelesaikan perselisihan 
industrial. Hal demikian menegaskan bahwa serikat pekerja berwenang atau kedudukannya diakui untuk mengajukan gugatan dan beracara di Pengadilan Hubungan Industrial terkait masalah ketenagakerjaan.

Berkaitan dengan pembahasan di atas, terdapat suatu kasus dalam Putusan Mahkamah Agung Nomor 959 K/Pdt.Sus-PHI/2017 yang terjadi antara para pekerja di PT. Petaling Mandra Guna yaitu Fandi Azhari, Wibowo Harto dan Samudra Pinem (Pemohon Kasasi) dengan PT. Petaling Mandra Guna (Termohon Kasasi) yang merupakan perusahaan pabrik pengolahan sawit tempat para pekerja tersebut bekerja.

Pada kasus tersebut para pekerja mendirikan serikat pekerja dengan tujuan untuk menuntut kekurangan upah lembur yang tidak sesuai di bayar, yakni mendirikan serikat pekerja yang tergabung dalam Federasi Kehutanan, Industri Umum, Perkayuan, Pertanian dan Perkebunan Serikat Buruh Sejahtera Indonesia (F-HUKATAN SBSI) PT. Petaling Mandra Guna tercatat dengan Nomor 560.6/03/PK-F.HUKATAN
SBSI/PT-PMG/VII/2015 oleh Dinas Tenaga Kerja dan Transmigrasi Kabupaten Muaro Jambi. Setelah terbentuknya serikat pekerja tersebut, pihak PT. Petaling Mandra Guna melakukan mutasi terhadap Ketua PK FHUKATAN SBSI dan ketiga pekerja.Tidak terima dengan keputusan perusahaan, ketiga pekerja dan pekerja lainnya yang tergabung dalam serikat pekerja hendak melakukan mogok kerja. Dari upaya yang dilakukan, tidak terlihat adanya niat baik dari pihak PT. Petaling Mandra Guna untuk menyelesaikan masalah yang ada, sehingga KORWIL KSBSI (Koordinator Wilayah Konfederasi Serikat Buruh Sejahtra Indonesia) Jambi menyampaikan permohonan mediasi ke Mediator PHI Dinas Tenaga Kerja dan Transmigrasi Kabupaten Muaro Jambi dan diberikan anjuran oleh Mediator PHI tersebut agar perusahaan membayar hak-hak pekerja sesuai Pasal 161 Undang-Undang Nomor 13 Tahun 2003 tentang Ketenagakerjaan yaitu: pesangon, penghargaan masa kerja dan uang penggantian hak. Agar perusahaan membayar kekurangan upah lembur. 
Pihak dari serikat pekerja PT. K/Pdt.Sus/HKI/2015, kuasa hukum Para Petaling Mandra Guna yang tergabung dalam F-HUKATAN SBSI dengan bantuan dari LBH KSBSI (Lembaga Bantuan Hukum Konfederasi Serikat Buruh Sejahtra Indonesia) mengajukan gugatan di Pengadilan Hubungan Industrial pada Pengadilan Negeri Jambi (Putusan Nomor 7/G/2017/PHI.Jmb) dan permohonan kasasi di Mahkamah Agung (Putusan Nomor 959 K/Pdt.SusPHI/2017) agar hak para pekerja dikembalikan sesuai dengan ketentuan dalam Undang-Undang Nomor 13 Tahun 2003 tentang Ketenagakerjaan dan Undang-Undang Nomor 21 Tahun 2000 tentang Serikat Pekerja/Serikat Buruh.

Pada putusan Mahkamah Agung Nomor $959 \quad$ K/Pdt.Sus-PHI/2017 tersebut, hakim memutuskan untuk menolak permohonan kasasi para Pemohon Kasasi. Putusan ini menguatkan putusan sebelumnya di Pengadilan Hubungan Industrial pada Pengadilan Negeri Jambi. Pertimbangan hakim Mahkamah Agung terhadap kasus ini adalah dikarenakan bahwa terdapat kasus lain yakni pelanggaran hak cipta pada Putusan Nomor 378Pekerja Pengurus KSBSI telah dilarang menggunakan nama dan logo SBSI; bahwa dengan adanya putusan a quo Kuasa Para Pemohon Kasasi yang menggunakan nama dan logo SBSI tidak sah sehingga tidak mempunyai legal standing.

Memperhatikan pokok perkara dan putusan hakim secara seksama pada Putusan Mahkamah Agung Nomor 959 K/Pdt.Sus-PHI/2017 yang intinya menolak permohonan kasasi karena terdapatnya kasus pelanggaran hak cipta atas nama dan logo yang dilakukan oleh LBH KSBSI pada putusan lain yaitu Putusan Mahkamah Agung Nomor 378K/Pdt.Sus/HKI/2015 sehingga kuasa hukum Para Pemohon tidak mempunyai legal standing, maka kemudian akan dikaji secara mendalam mengenai permasalahan tersebut dalam karya tulis (skripsi) dengan judul "Legal Standing Serikat Pekerja dalam Mengajukan Gugatan pada Pengadilan Hubungan Industrial (Studi Kasus: Pelanggaran Hak Cipta atas Nama dan Logo Serikat Pekerja pada Putusan Nomor 7/G/2017/PHI.Jmb juncto Putusan 


\section{ERA 9lunal Ollmiah olmu Glukum \\ Volume 17, No. 1, Juni 2019}

\section{Mahkamah Agung Nomor 959 K/Pdt.Sus-PHI/2017)."}

\section{B. Perumusan Masalah}

Berdasarkan latar belakang belakang masalah di atas, maka dapat dirumuskan permasalahan sebagai berikut:

1. Bagaimana kedudukan serikat pekerja sebagai kuasa hukum berkaitan dengan legal standing para pihak yang ditolak oleh Hakim Mahkamah Agung berkaitan dengan pelanggaran hak cipta atas nama dan logo pada Pengadilan Hubungan Industrial (Studi Kasus: Pelanggaran Hak Cipta atas Nama dan Logo Serikat Pekerja pada Putusan Nomor 7/G/2017/PHI.Jmb juncto Putusan Mahkamah Agung Nomor 959 K/Pdt.Sus-PHI/2017)?

2. Bagaimana upaya hukum yang dapat dilakukan oleh LBH (Lembaga Bantuan Hukum) KSBSI Prov. Jambi sebagai kuasa hukum serikat pekerja SBSI yang telah dinyatakan tidak mempunyai legal standing (Studi Kasus: Pelanggaran Hak Cipta atas Nama dan Logo
Serikat Pekerja pada Putusan Nomor 7/G/2017/PHI.Jmb juncto Putusan Mahkamah Agung Nomor 959 K/Pdt.Sus-PHI/2017)?

\section{Metode Penelitian}

1. Jenis Penelitian

Jenis penelitian yang digunakan di dalam penelitian ini adalah penelitian hukum normatif. Penggunaan metode penelitian hukum normatif dikarenakan penulisan ini meneliti beberapa peraturan perundangundangan untuk mendapatkan koherensi antara putusan hakim pada Pengadilan Hubungan Industrial dengan hukum positif yang belaku. ${ }^{2)}$

2. Jenis dan Teknik Pengumpulan Data Sebagaimana jenis penelitian yang digunakan adalah penelitian hukum normatif, maka diperlukan data penelitian untuk dapat memecahkan isu hukum dan sekaligus memberikan preskripsi mengenai apa yang seyogianya. 3 ) Sumber-sumber penelitian dapat dibedakan menjadi

2) Peter Mahmud Marzuki, Penelitian Hukum, Cetakan ke-8. (Jakarta: Kencana Prenada Media Group, 2013), hal. 47.

3) Ibid., hal. 35 . 
sumber-sumber penelitian yang berupa bahan hukum primer, sekunder dan non-hukum. Bahan hukum primer yang akan penulis gunakan terdiri dari: Kitab Undang-Undang Hukum Perdata; Undang-Undang Nomor 21 Tahun 2000 tentang Serikat Buruh; Undang-Undang Nomor 18 Tahun 2003 tentang Advokat; UndangUndang Nomor 13 Tahun 2003 tentang Ketenagakerjaan; UndangUndang Nomor 2 Tahun 2004 tentang Perselisihan Hubungan Industrial; Undang-Undang Nomor 12 Tahun 2011 tentang Pembentukan Peraturan Perundang-Undangan.

Bahan Hukum Sekunder yang digunakan berupa semua publikasi tentang hukum yang bukan merupakan dokumen-dokumen resmi. Publikasi tentang hukum meliputi buku-buku, kamus-kamus hukum, jurnal hukum, artikel, dan internet. Bahan nonhukum yang digunakan adalah Kamus Besar Bahasa Indonesia (KBBI) dan data hasil wawancara.

Pengumpulan data dalam penelitian ini menggunakan metode mengumpulkan data melalui studi dokumen atau kepustakaan (library research) yaitu melakukan penelitian terhadap berbagai sumber bacaan seperti buku-buku yang berkaitan dengan ketenagakerjaan, artikel dan juga berita yang diperoleh dari internet.

\section{Pendekatan Penelitian}

Metode pendekatan yang digunakan dalam penelitian ini adalah pendekatan undang-undang (statute approach) yang dilakukan dengan menelaah semua undang-undang dan regulasi yang berkaitan dengan isu hukum yang ada dan pendekatan kasus (case approach) yang dilakukan dengan cara telaah terhadap kasus-kasus yang berkaitan dengan isu yang dihadapi yang telah menjadi putusan pengadilan dan telah mempunyai kekuatan yang tetap.

4. Spesifikasi Penelitian

Spesifikasi penelitian dalam penulisan ini adalah penelitian preskriptif $^{4)}$. Preskriptif artinya memberi preskripsi mengenai apa yang seyogianya. Spesifikasi penelitian ini ditujukan untuk mendeskripsikan

\footnotetext{
4) Ibid., hal. 181.
} 


\section{हृरिय

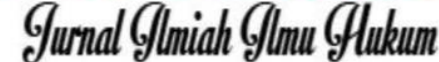 \\ Volume 17, No. 1, Juni 2019}

mengenai legal standing serikat pekerja dalam mengajukan gugatan di Pengadilan Hubungan Industrial berdasarkan Peratutan Perundangundangan.

\section{Teknik Analisis Data}

Analisis data merupakan kegiatan dalam penelitian yang berupaya melakukan kajian atau telaah terhadap hasil pengolahan data yang dibantu dengan teori yang telah didapatkan sebelumnya. Secara sederhana analisis data ini disebut sebagai kegiatan menelaah dan kemudian membuat suatu kesimpulan terhadap hasil penelitian dengan pikiran sendiri dengan bantuan teori. $^{5)}$

\section{PEMBAHASAN}

A. Analisis Kedudukan Serikat

Pekerja sebagai Kuasa Hukum berkaitan dengan Legal Standing para Pihak yang Ditolak oleh Hakim Mahkamah Agung dalam Pelanggaran Hak Cipta atas Nama

\footnotetext{
${ }^{5)}$ Tunjung Herning Sitabuana (b), "Penyelesaian Masalah Diskriminasi Terhadap Etnis Cina (Studi Tentang Perkembangan Politik Hukum di Bidang Kewarganegaraan Republik Indonesia)", (Ringkasan Disertasi Doktor, Universitas Diponegoro, 2011), hal. 86.
}

\section{Hubungan Industrial}

Kedudukan serikat pekerja sebagai kuasa hukum diatur oleh UUPPHI (Undang-Undang Penyelesaian Perselisihan Hubungan Industrial) Nomor 2 Tahun 2004 tentang Penyelesaian Perselisihan Hubungan Industrial Pasal 87 dan Pada Pasal 25 Ayat (1) Huruf b Undang-Undang Nomor 21 Tahun 2000 tentang Serikat Pekerja juga diatur tentang kedudukan serikat pekerja sebagai kuasa hukum. Kedua peraturan tersebut merupakan dasar hukum bagi serikat pekerja ketika terjadi suatu perselisihan hubungan industrial yang membutuhkan penyelesaian di pengadilan Hubungan Industrial, maka kedudukannya diakui untuk mewakili para pihak untuk beracara di Pengadilan.

Pertama, perlu diingat bahwa perselisihan dalam hubungan industrial terbagi menjadi empat sesuai dengan UUPPHI Nomor 2 Tahun 2004, yaitu perselisihan hak, perselisihan kepentingan, perselisihan pemutusan hubungan kerja, dan 
perselisihan antar serikat pekerja dalam satu perusahaan. Penyelesaian terhadap perselisihan-perselisihan tersebut dilakukan dengan perundingan bipatrit, mediasi, konsiliasi, arbitrase dan Pengadilan Hubungan Industrial. Upaya penyelesaian ini dapat dilihat sebagai bentuk perlindungan negara terhadap pihak-pihak apabila terjadi suatu perselisihan. H. Salim HS mendefinisikan perlindungan hukum sebagai upaya atau bentuk pelayanan yang diberikan oleh hukum kepada subjek hukum serta menjadi objek yang dilindungi 6 ). Pengadilan Hubungan Industrial yang secara nyata menyelenggarakan Kekuasaan Kehakiman dipandang sebagai salah satu fungsi utama dari negara yang menjamin perlindungan hukum bagi penyelesaian permasalahan ketenagakerjaan. Pengadilan Hubungan Industrial menurut Undang-Undang diartikan sebagai Pengadilan yang khusus dibentuk di

6) H. Salim HS dan Erlies Seoptiana Nurbani, Penerapan Teori Hukum pada Penelitian Tesis dan Disertasi, (Jakarta: PT Raja Grafindo, 2013), hal. 262. lingkungan Pengadilan Negeri yang berwenang memeriksa, mengadili dan memberi putusan terhadap perselisihan hubungan industrial sebagaimana diatur pada Pasal 1 Angka (17) UUPPHI Nomor 2 Tahun 2004 tentang Penyelesaian Perselisihan Hubungan Industrial. Kedua, Pengadilan Hubungan Industrial sebagai penyelenggara kekuasaan kehakiman yang berada pada lingkup Peradilan Umum menerapkan Hukum Acara Perdata dalam menyelesaikan Perselisihan Hubungan Industrial, diatur pada Pasal 57 UUPPHI Nomor 2 Tahun 2004 tentang Penyelesaian Perselisihan Industrial, Hukum Acara Perdata mengenal gugatan dan hak untuk mengajukan gugatan. Hak dan gugatan berkaitan erat dengan hak dari penggugat untuk mengajukan gugatan pada Pengadilan. Menurut M. Yahya Harahap, dalam Hukum Acara Perdata yang bertindak sebagai penggugat haruslah benar-benar orang yang memiliki kedudukan dan kapasitas yang tepat menurut 
hukum ${ }^{7}$ ). Kedudukan dan kapasitas seseorang untuk mengajukan gugatan diperlukan ketika terdapat hak dan kepentingan yang dirugikan serta menimbulkan perselisihan, kemudian perselisihan diharapkan dapat terselesaikan secara adil dan menjamin kepastian hukum, yaitu jaminan bahwa hukum dijalankan, bahwa yang berhak menuntut hukum dapat diperoleh haknya dan bahwa putusan dapat dilaksanakan. Sudikno ${ }^{8)}$ dalam definisinya tentang kepastian hukum menambahkan bahwa kepastian hukum merupakan perlindungan yustiabel terhadap tindakan sewenang-wenang, yang berarti seseorang dapat memperoleh sesuatu yang diharapkan dalam keadaan tertentu.

$$
\text { Pada lingkup hubungan }
$$
industrial tidak pernah terlepas dari permasalahan antar para pihak baik antar pekerja dan pengusaha maupun serikat pekerja. Organisasi serikat

7) M. Yahya Harahap, Hukum Acara Perdata, (Jakarta: Rajawali Press, 2012), hal. 111.

8 Sudikno Mertokusumo, Mengenal Hukum Suatu Pengantar, (Yogyakarta: Liberty, 1999), hal. 47. pekerja didefinisikan berdasarkan Undang-Undang Nomor 21 Tahun 2000 tentang Serikat Pekerja pada dasarnya adalah alat yang utama bagi pekerja untuk melindungi dan memperjuangkan kedudukan yang baik, bertujuan untuk memberikan perlindungan, pembelaan, dan meningkatkan kesejahteraan bagi anggotanya serta mempunyai peran dan fungsi yang strategis di dalam pelaksanaan hubungan industrial. Salah satu peran dan fungsi serikat pekerja yang strategis dalam pelaksanaan hubungan industrial adalah serikat pekerja, federasi, dan konfederasi diberikan hak khusus untuk mewakili pekerja dalam menyelesaikan perselisihan industrial. Peran dan fungsi tersebut dijamin oleh undang-undang dan merupakan suatu kepastian hukum mutlak selama ketentuan tersebut tidak diganti. Ketentuan yang harus dipatuhi oleh serikat pekerja, federasi, dan konfederasi serikat pekerja untuk menjalankan fungsi dan peran tersebut adalah harus mempunyai nomor bukti pencatatan di Dinas 
Tenaga Kerja (Pasal 25 Ayat (1)

Huruf b Undang-Undang Nomor 21 Tahun 2000 tentang Serikat Pekerja), ketika sebuah serikat perkerja memenuhi ketentuan ini, maka serikat pekerja tersebut dapat bertindak sebagai kuasa hukum untuk mewakili anggotanya beracara di Pengadilan Hubungan Industrial (Pasal 87 UUPPHI Nomor 2 Tahun 2004 tentang Penyelesaian

Perselisihan Hubungan Industrial).

Penyelesaian Perselisihan

Industrial melalui Pengadilan

Hubungan Industrial menerapkan

Hukum Acara Perdata, yaitu pada

Pasal 57 UUPPHI Nomor 2 Tahun

2004 tentang Penyelesaian

Perselisihan Industrial, Hukum

Acara Perdata mengenal gugatan

dan hak untuk mengajukan gugatan.

Zainal Asikin 9 ) memberikan

pengertian bahwa yang dimaksud dengan gugatan adalah suatu tuntutan yang disampaikan kepada ketua Pengadilan yang berwenang oleh seseorang mengenai suatu hal

9) Zainal Asikin, Hukum Acara Perdata di Indonesia, (Jakarta: Kencana, 2015), hal. 19. akibat adanya persengketaan dengan pihak lainnya yang kemudian mengharuskan hakim memeriksa tuntutan tersebut menurut cara tertentu yang kemudian melahirkan putusan terhadap putusan tersebut. Kemudian mengacu kepada ketentuan tersebut, serikat pekerja dalam menjalankan kedudukannya sebagai kuasa hukum berarti juga memiliki hak-hak yang sama dengan hak kuasa hukum pada Hukum Acara Perdata, yaitu berhak melakukan segala wewenang yang diatur dalam Hukum Acara Perdata termasuk mengajukan gugatan pada Pengadilan, yang dalam lingkupnya yaitu Pengadilan Hubungan Industrial. Hak untuk mengajukan gugatan tersebut pada Black's Law Dictionary diartikan “A Party's right to make legal claim or seek judicial enforcement of a duty or right."10) Legal Standing diperlukan ketika seseorang ataupun sekelompok orang melakukan

$10)$ Bryan A. Garner, Black's Law Dictionary Tenth Edition, (St. Paul, Minn: West Publishing co, 1990), hal. 1625. 
perbuatan hukum di Pengadilan, kedudukan dan dan kapasitasnya dalam melakukan perbuatan hukum harus tepat menurut hukum, sejalan dengan pendapat M. Yahya Harahap, salah dalam bertindak sebagai penggugat mengakibatkan gugatan mengandung cacat formil atau error in persona 11). Pertimbangan Hakim Pengadilan Hubungan Industrial dan Mahkamah Agung perihal Legal Standing kuasa hukum, dalam hal ini advokat serikat pekerja LBH KSBSI (Konfederasi Serikat Buruh Sejahtera Indonesia) yang dinyatakan tidak absah dengan alasan terdapat kasus pelanggaran hak cipta atas nama dan logo yang dilakukan oleh LBH KSBSI pada Putusan Nomor 7/G/2017/PHI.Jmb juncto Putusan Mahkamah Agung Nomor 959 K/Pdt.Sus-PHI/2017 jika ditinjau secara seksama tidak termasuk ke dalam empat jenis perselisihan industrial pada hubungan industrial. Meninjau

11) M. Yahya Harahap, Hukum Acara Perdata, (Jakarta: Rajawali Press, 2012), hal. 111.
Putusan Nomor 378 K/Pdt.SusHKI/2015 yang menjadi dasar utama pertimbangan hakim dalam memutus perihal legal standing kuasa hukum pada Putusan Nomor 7/G/2017/PHI.Jmb juncto Putusan Mahkamah Agung Nomor 959 K/Pdt.Sus-PHI/2017 sebenarnya pokok permasalahan pada Pengadilan Niaga tersebut adalah menguji siapa pencipta dari nama dan logo Serikat Pekerja SBSI dan bukan sama sekali tentang isu ketenagakerjaan. Pada hakikatnya Pengadilan dalam menjalankan otoritasnya harus mengedepankan tercapainya tujuan hukum. Apabila Pengadilan memutus suatu perkara hanya berdasarkan terdapatnya kasus lain yang telah diputus oleh Lembaga Peradilan lainnya dan bukan berdasarkan sumber-sumber hukum yang ada, maka dapatlah dipertanyakan apakah putusan hakim tersebut sudah benar.

Perlu digaris bawahi bahwa antara masalah hak kekayaan intelektual dan ketenagakerjaan 
merupakan dua hal yang berbeda, permasalahan hak cipta adalah wewenang dari Pengadilan Niaga, sedangkan masalah ketenagakerjaan adalah wewenang dari Pengadilan Hubungan Industrial. Pengadilan Hubungan Industrial harus dilihat sebagai jalur tersendiri sehingga antara Pengadilan Niaga dan Pengadilan Hubungan Industrial keduanya mengatur kewenangan yang berbeda dengan kompetensi absolut yang berbeda. Pengadilan Hubungan Industrial memiliki karakteristik yang berbeda dari Peradilan-Peradilan lainnya, yaitu dasar ontologisnya dan dibentuk oleh UUPPHI Nomor 2 Tahun 2004 tentang Penyelesaian Perselisihan Hubungan Industrial 12 ), sebagaimana ditegaskan oleh Mohammad Fandrian, seorang advokat pada LBHN PP KEP (SPSI) Serikat Pekerja Seluruh Indonesia.

12) Penulis, Wawancara dengan Dr. Reytman Aruan, S.H., M.Hum, Kepala Sub Direktorat Penyelesaian Perselisihan Hubungan Industrial (Jakarta: Kementerian Ketenagakerjaan, 6 Mei 2019).
Advokat pada LBH KSBSI dalam menjalankan perannya sebagai kuasa hukum dari serikat pekerja SBSI tidak dapat dikatakan sebagai perbuatan yang melanggar hukum dikarenakan memakai nama dan logo yang mengandung unsur SBSI yang telah dilarang untuk digunakan pada Putusan HKI Nomor 378-K/Pdt.Sus-PHI/2017. Kuasa hukum LBH KSBSI sebagai penerima kuasa pada kasus ini terlibat secara langsung dalam kepengurusan yaitu sebagai Koordinator Wilayah LBH KSBSI Prov. Jambi sekaligus memangku jabatan sebagai seorang advokat. Jika memandang dari sisi kuasa hukum sebagai advokat, seorang advokat dalam bertindak mewakili para pihak tidak harus selalu bernaung di $\mathrm{LBH}$ atau firma tertentu untuk dapat bertindak sebagai kuasa hukum dan mendapat legal standing. Pertimbangan hakim yang mempermasalahkan legal standing karena suatu LBH menggunakan nama dan logo yang sebelumnya pernah dilarang maka tidak tepat 
jika menunjuk pada posisi kuasa hukum tersebut sebagai advokat karena LBH KSBSI bukan merupakan pengurus serikat pekerja, melainkan adalah sebuah entitas yang berbeda yang bernama lembaga bantuan hukum. Seorang advokat memiliki legal standing ketika ia diberi kuasa secara persoon dan memenuhi ketentuan advokat pada Undang-Undang Nomor 18 Tahun 2003 tentang Advokat. Sedangkan memandang dari sisi kuasa hukum sebagai anggota organisasi serikat pekerja, kuasa hukum, yakni Roida Pane adalah Koordinator Wilayah LBH KSBSI Prov. Jambi yang terlibat langsung dalam keanggotaan dan kepengurusan serikat pekerja ini serta serikat pekerja telah tercatat di Dinas Tenaga Kerja.

Reytman Aruan, seorang Kepala Sub Direktorat Penyelesaian Perselisihan Hubungan Industrial pada Kementerian Ketenagakerjaan memandang bahwa penentu dari legal standing kuasa hukum dalam mewakili serikat pekerja bukan pada nama dan lambang, melainkan apabila pekerja tersebut merupakan anggota daripada serikat pekerja, maka serikat pekerja boleh menjadi kuasa hukum bagi anggotanya ${ }^{13)}$. Advokat LBH KSBSI sebagai kuasa hukum pada kasus ini dalam mewakili para pihak memang secara nyata menggunakan nama KSBSI yang mengandung unsur nama SBSI namun secara kelembagaan, advokat di dalamnya jika dipandang bukan merupakan serikat pekerja maupun pengurus serikat pekerja maka seharusnya posisinya tidak dipermasalahkan. Apabila kuasa hukum tersebut anggota serikat pekerja, mungkin hal tersebut dapat menjadi pertimbangan hakim, namun hal itu pun debatable karena syarat sahnya suatu serikat pekerja didasarkan pada pencatatan di Dinas Tenaga Kerja dan KSBSI telah tercatat di

13 ) Penulis, Wawancara dengan Dr. Reytman Aruan, S.H., M.Hum, Kepala Sub Direktorat Penyelesaian Perselisihan Hubungan Industrial (Jakarta: Kementerian Ketenagakerjaan, 6 Mei 2019). 
Dinas Tenaga Kerja Pasal 25 Ayat (1) Undang-Undang Nomor 21 Tahun 2001 tentang Serikat Pekerja merupakan legal standing yang undang-undang berikan secara khusus bagi serikat pekerja sebagai kuasa hukum untuk mewakili anggotanya. Terlebih, tidak diperlukan izin pada Pengadilan Hubungan Industrial sebagai advokat jika seseorang hendak menjadi kuasa hukum bagi anggotanya, bahkan seseorang bukan sarjana hukum juga tidak dipermasalahkan sepanjang serikat pekerja tersebut sudah tercatat di Dinas Tenaga Kerja.

Muchtar Pakpahan sebagai pihak Penggugat pada kasus hak cipta dalam kasus ini melihat dari sudut pandang yang berbeda, baginya legal standing serikat pekerja ditentukan dari nama dan logo yang digunakan serikat pekerja, apakah hal tersebut sah atau tidak secara hukum ${ }^{14}$ ). Ketika suatu Putusan

14 ) Penulis, Wawancara dengan Prof. Dr. Muchtar Pakpahan, S.H., M.H, Pemohon Kasasi
Pengadilan pada konteksnya hak cipta dikeluarkan dan isinya melarang penggunaan nama dan logo oleh serikat pekerja lainnya, maka putusan tersebut juga berlaku terhadap Undang-Undang Nomor 21 Tahun 2000 tentang Serikat Pekerja karena masalah nama dan logo yang dilarang tidak terbatas pada ranah Hak Kekayaan Intelektual saja, melainkan hukum dalam hal ini Undang-Undang Hak Cipta harus tetap melindungi pencipta suatu karya intelektual. LBH KSBSI yang memakai nama dan logo yang telah dilarang adalah bertentangan dengan undang-undang dan bahkan tergolong tindakan ilegal. Legal standing dari kuasa hukum pada awalnya diatur oleh UndangUndang Advokat, akan tetapi saat suatu serikat pekerja bertindak sebagai kuasa hukum maka UndangUndang Advokat juga kemudian berlanjut ke Undang-Undang Serikat Pekerja.

pada Putusan Nomor 378 K/Pdt.Sus-HKI/2015 (Jakarta: Pasca Sarjana Universitas Kristen Indonesia). 
Kuasa hukum pada perkara ini, Roida Pane mengakui dirinya tergabung di dalam kepengurusan KSBSI dengan jabatan sebagai Ketua Koordinator Wilayah KSBSI Jambi. Legal standing nya ditinjau dari posisi keanggotaan serikat pekerja adalah absah selama dirinya masih tergabung di dalam serikat pekerja yang tercatat di Dinas Tenaga Kerja, jika ditinjau dari posisinya sebagai advokat dirinya telah menerima kuasa khusus dan telah menunjukkan identitas sebagai seorang advokat (berita sumpah sebagai seorang advokat dari Pengadilan Tinggi Jambi dan kartu anggota di Peradi). Jabatan dari kuasa hukum dalam mewakili para pihak ini adalah sebagai advokat yang sah sekaligus anggota dan pengurus organisasi serikat pekerja, sehingga legal standing nya absah sebenarnya menurut UndangUndang $^{15)}$.

${ }^{15)}$ Penulis, Wawancara dengan Roida Pane, S.H, Advokat pada LBH KSBSI Jambi dan Ketua Koordinator Wilayah KSBSI Jambi (Jakarta: Wawancara Via Telepon, 21 Juni 2019).
Pendapat tentang korelasi antara legal standing serikat pekerja dan pelanggaran Hak Cipta dipandang tidak ada, selaku ahli Hukum Kekayaan Intelektual, Simona Bustani menegaskan bahwa pendaftaran sebuah organisasi yang berbentuk serikat pekerja bukan termasuk pendaftaran merek dikarenakan tidak ada tindakan mengambil keuntungan dari sisi Hak Kekayaan Intelektual di dalamnya 16 ). Sebagaimana logo pada konteks hak cipta dibedakan menjadi logo sebagai ciptaan murni (lukisan dan ciptaan) dan logo sebagai merek, maka tujuan dari dicantumkannya nama dan logo adalah memberikan suatu identitas bagi organisasi, yaitu logo sebagai ciptaan murni. Hak cipta kemudian timbul secara otomatis saat seseorang menciptakan suatu karya intelektual dan bukan dari pencatatan, sehingga yang berhak mengajukan keberatan bahwa logo

16 ) Penulis, Wawancara dengan Dr. Simona Bustani, S.H., M.H, Dosen Hak Kekayaan Intelektual (Jakarta Universitas Trisakti, $21 \mathrm{Mei}$ 2019). 
pada konteks hak cipta digunakan oleh orang lain sebagai merek adalah pencipta dari suatu karya intelektual tersebut di Pengadilan Niaga. Nama dan logo yang dipakai oleh LBH KSBSI sendiri bukan bertujuan sebagai kepentingan merek untuk memperoleh keuntungan, hal itu hanya merupakan permasalahan penggunaan logo oleh pihak lain yang seharusnya terbatas pada konteks Hak Kekayaan Intelektual saja, bukan malah dibawa ke ranah Pengadilan Hubungan Industrial.

Bertitik tolak pada kompetensi relatif dan absolut Pengadilan dalam menangani perkara, persoalan nama dan logo pada kasus ini bukan merupakan wewenang dari Pengadilan Hubungan Industrial. Sejalan dengan pendapat keempat ahli diatas, dalam hal ini dapat dikatakan Pengadilan Hubungan Industrial telah memutus di luar apa yang dipermasalahkan, permasalahan nama dan logo tidak dapat dijadikan alasan untuk menyatakan sebuah gugatan tidak sah, mengingat sebenarnya yang menjadi gugatan bukan terkait hal ini (hak cipta) melainkan yang menjadi gugatan para penggugat pada mulanya adalah kekurangan upah lembur. Eksepsi yang dapat dibuat oleh Tergugat seharusnya hanya berkisar pada peraturan yang diatur dalam hubungan industrial, terutama terkait UUPPHI Nomor 2 Tahun 2004 tentang Penyelesaian Perselisihan Hubungan Industrial, yaitu jenis perselisihan hak, kepentingan, pemutusan hubungan tenaga kerja, dan perselisihan antar serikat pekerja dalam suatu perusahaan, permasalahan nama dan logo tidaklah termasuk jenis perselisihan di hubungan industrial. Eksepsi dari tergugat tersebut sudah berada di luar konteks ketenagakerjaan yang seharusnya dikesampingkan oleh Pengadilan, bukan malah diterima dan menjadi keliru atau obscuur libel. Hal tersebut telah melampaui kewenangan dari Pengadilan Hubungan Industrial, Pengadilan 
Hubungan Industrial tidak berhak menguji apakah suatu lambang serikat pekerja telah digunakan dengan benar atau tidak, melainkan yang perlu diuji adalah apakah serikat pekerja telah tercatat di Dinas Tenaga Kerja karena undangundang menyatakan serikat pekerja yang tercatat di Dinas Tenaga Kerja berhak bertindak sebagai kuasa hukum mewakili anggotanya. Hakim dalam mengambil keputusan pada kasus ini pun tidak menggunakan dasar pertimbangan yang jelas, yaitu dalil-dalil atau pasal-pasal yang seharusnya, Hakim Mahkamah Agung juga tidak memberikan kepastian hukum karena tidak menyelesaikan perkara sesuai permohonan atau gugatan yang pada akhirnya menyebabkan ketidakpastian hukum.

B. Analisis Upaya Hukum yang dapat Dilakukan oleh LBH KSBSI Prov. Jambi sebagai Kuasa Hukum Serikat Pekerja SBSI yang telah dinyatakan

\section{tidak mempunyai Legal Standing}

Pasal 57 UUPPHI Nomor 2 Tahun 2004 tentang Penyelesaian Perselisihan Hubungan Industrial menyatakan bahwa "Hukum acara yang berlaku pada Pengadilan Hubungan Industrial adalah Hukum Acara Perdata yang berlaku di lingkungan Peradilan Umum, kecuali yang diatur secara khusus dalam UUPPHI Nomor 2 Tahun 2004 tentang Penyelesaian Perselisihan Hubungan Industrial", dari bunyi pasal di atas maka dalam proses peradilannya memberlakukan Hukum Acara Perdata, termasuk mengajukan upaya hukum. Pada Pasal 56 UUPPHI Nomor 2 Tahun 2004 tentang Penyelesaian Perselisihan Hubungan Industrial mengatakan Pengadilan hubungan industrial bertugas dan berwenang memeriksa dan memutus di tingkat pertama mengenai perselisihan hak dan perselisihan pemutusan hubungan kerja, sedangkan di tingkat pertama dan terakhir 
mengenai perselisihan kepentingan dan perselisihan antar serikat pekerja dalam satu perusahaan. Upaya hukum banding tidak dikenal, jadi perkara yang selesai pada tingkat pertama (Pengadilan Hubungan Industrial pada Pengadilan Negeri) tetapi apabila ada pihak yang menolak, maka pihak yang bersangkutan dapat mengajukan upaya hukum kasasi di Mahkamah Agung sebagai bentuk perlindungan hukum khusus untuk perselisihan hak dan perselisihan PHK (Pemutusan hubungan kerja). Pengadilan tingkat pertama, Judex Factie yaitu peradilan yang bertugas memeriksa fakta-fakta dan buktibukti perkara, sedangkan tingkat kasasi Mahkamah Agung tidak lagi memeriksa fakta-fakta dan buktibukti perkara. Mahkamah Agung hanya meneliti apakah Pengadilan tingkat pertama telah menerapkan peraturan perundang-undangan secara tepat atau tidak.

LBH KSBSI sebagai kuasa hukum ditetapkan oleh Pengadilan
Hubungan Industrial pada Pengadilan Negeri Jambi tidak memiliki legal standing atau kedudukan yang sah untuk mewakili beracara di Pengadilan. Hakim setelah memeriksa fakta dan bukti perkara dalam pertimbangannya pada Putusan Nomor 7/G/2017/PHI.Jmb mengabulkan eksepsi dari Tergugat, yakni PT. Petaling Mandra Guna mengajukan jawaban bahwa dengan dasar LBH KSBSI tidak memiliki kompetensi/kewenangan untuk menerima kuasa dari para penggugat dikarenakan masih mempergunakan nama SBSI walaupun sudah ada larangan untuk itu sesuai dengan putusan Pengadilan yang telah mempunyai kekuatan hukum tetap, yaitu Putusan HKI Nomor 378K/Pdt.Sus-PHI/201. Pihak LBH KSBSI dalam mewakili para pekerja beranjak dari dikeluarkannya putusan tersebut tidak menerima hasil putusan Hakim Pengadilan Hubungan Industrial pada Pengadilan Negeri Jambi, sehingga 
melakukan upaya hukum kasasi ke Mahkamah Agung.

Pada upaya hukum kasasi, pihak LBH KSBSI melanjutkan perkara tersebut dengan tujuan Hakim Mahkamah Agung membatalkan putusan pada tingkat pertama. Namun, Hakim Mahkamah Agung kemudian menguatkan pertimbangan Judex Factie dan mengungkapkan bahwa Pengadilan Hubungan Industrial pada Pengadilan Negeri Jambi tidak salah dalam menerapkan hukum karena ada larangan penggunaan nama dan logo SBSI, pada akhirnya permohonan kasasi para pemohon ditolak. Berlandaskan pada ketentuan Hukum Acara Perdata, apabila pihak LBH KSBSI sebagai pemohon telah menolak hasil putusan Mahkamah Agung, maka upaya hukum selanjutnya yang dapat dilakukan adalah Peninjauan Kembali. Peninjauan kembali sebagai upaya hukum luar biasa seharusnya dapat diajukan pada kasus ini, akan tetapi diketahui telah dikeluarkan SEMA (Surat Edaran Mahkamah Agung) Nomor 3 Tahun 2018, ditegaskan pada bagian Perdata Khusus tentang Upaya Hukum bahwa Putusan Pengadilan Hubungan Industrial dalam perkara perselisihan kepentingan dan perselisihan antar serikat dalam satu perusahaan dan bersifat tetap, sedangkan putusan mengenai perselisihan hak dan perselisihan pemutusan hubungan kerja dapat diajukan kasasi sebagai upaya hukum terakhir sesuai Pasal 56, Pasal 57, Pasal 109 dan Pasal 110 UUPPHI Nomor 2 Tahun 2004 tentang Perselisihan Hubungan Industrial, sehingga dalam perkara Perselisihan Hubungan Industrial tidak ada upaya hukum Peninjauan Kembali.

SEMA Nomor 3 Tahun 2018 yang dikeluarkan oleh Mahkamah Agung merupakan suatu benturan secara langsung bagi Pasal 56 dan 57 UUPPHI Nomor 2 Tahun 2004 tentang Penyelesaian Perselisihan Industrial. Ketentuan pada Pasal 56 
UUPPHI mengenai perselisihan hak dan pemutusan hubungan kerja sebagai tingkat pertama mengenal upaya hukum yang dijelaskan pada pasal selanjutnya yaitu Pasal 57 UUPPHI, yaitu pemberlakuan Hukum Acara Perdata pada Pengadilan Hubungan Industrial kecuali diatur lain oleh UUPPHI Nomor 2 Tahun 2014 tentang Penyelesaian Perselisihan Industrial. Bagi perselisihan hak dan perselisihan pemutusan hubungan kerja pada awalnya diperkenankan untuk mengajukan upaya hukum termasuk Peninjauan Kembali, namun kehadiran SEMA Nomor 3 Tahun 2018 justru menimbulkan ketidakpastian hukum, peraturan hukum mana yang harus dipatuhi. Pada faktanya SEMA tidak termasuk ke dalam jenis dan hierarki Peraturan Perundang-Undangan, yakni Pasal 7 ayat (1) UndangUndang Nomor 12 Tahun 2011 tentang Pembentukan Peraturan Perundang-Undangan. Integrasi dari antar regulasi sangatlah diperlukan menyangkut tujuan dari hukum itu sendiri ialah kepastian, keadilan dan kemanfaatan hukum, akan sangat menimbulkan suatu kerancuan ketika masyarakat dan para praktisi hukum menghadapi benturan antar peraturan seperti yang terjadi antara SEMA Nomor 3 Tahun 2018 dengan UUPPHI Nomor 2 Tahun 2004 tentang Penyelesaian Perselisihan Industrial, terlebih SEMA Nomor 3 Tahun 2018 bukan termasuk jenis dan hierarki Peraturan Perundang-Undangan maupun sesuatu yang diatur lain oleh UUPPHI Nomor 2 Tahun 2004 tentang Penyelesaian Perselisihan Industrial (Pasal 57 UUPPHI) namun dikeluarkan oleh instansi yang berwenang serta memangku otoritas kekuasaan kehakiman yaitu Mahkamah Agung.

Kehadiran dari SEMA Nomor 3 Tahun 2018 terhadap praktek peninjauan kembali pada Pengadilan Hubungan Industrial memberikan beberapa pendapat menurut ahli pada bidang hubungan industrial. Mohammad Fandrian, selaku 
advokat pada LBHN PP FSP KEP

SPSI tidak berpihak kepada Surat Edaran Mahkamah Agung tersebut, menurut pendapatnya sebagai seorang advokat tidak adanya upaya hukum peninjauan kembali setelah kasasi tidak sesuai dengan prinsip kepastian hukum. Suatu putusan Mahkamah Agung dianggap telah incracht, sehingga apabila mengajukan upaya hukum peninjauan kembali dapat dipastikan NO (Niet Ontvankelijke Verklaard) sesuai dengan pengalaman pribadinya ketika mewakili pihak yang berperkara di Pengadilan. Terhalangnya upaya hukum peninjauan kembali sama sekali tidak sejalan dengan prinsip pada Hukum Acara Perdata yang menerapkan hal tersebut demi tercapainya tujuan hukum dan guna memperoleh hukum yang sebenarbenarnya dan adil bagi kedua pihak yang berperkara. LBH KSBSI sehingga pada posisi sekarang ini hanya mampu mengajukan upaya hukum sampai pada tingkat kasasi yaitu berhenti sampai putusan
Mahkamah Agung yang terakhir (Putusan Nomor 959K/Pdt.SusPHI/2017) yang dianggap telah incracht.

Menurut Muchtar Pakpahan, sebagai pihak yang dimenangkan perihal perkara Hak Cipta logo SBSI (Putusan Nomor 378 K/Pdt.SusHKI/2015) memandang SEMA Nomor 3 Tahun 2018 tidak menghalangi upaya hukum peninjauan kembali jika terdapat novum atau alat bukti baru sebab SEMA bukan termasuk jenis dan hierarki peraturan perundangundangan. Langkah kongkrit yang dapat diambil oleh LBH KSBSI yang telah dinyatakan tidak memiliki legal standing menurutnya adalah mengganti nama LBH yang tidak menggunakan nama KSBSI yang telah dilarang atau kuasa hukum tersebut memiliki kantor pribadi yang tidak berada di bawah nama LBH KSBSI, karena permasalahan utama bukan terletak pada kecakapan advokat sebagai kuasa hukum melainkan 
penggunaan nama dan logo yang dilarang.

Pembatasan pengajuan upaya hukum oleh SEMA Nomor 3 Tahun 2018 juga diakui oleh Reytman Aruan, Kepala Sub Direktorat Penyelesaian Perselisihan Hubungan Industrial. Beliau mempertanyakan keberadaan Surat Edaran Mahkamah Agung yang nyatanya pada praktek bersifat regelling atau regulasi. Pengaturan mengenai pentiadaan upaya hukum peninjauan kembali pada SEMA Nomor 3 Tahun 2018 dipandang tidak tepat serta menimbulkan kerancuan pada praktek penyelesaian perselisihan industrial, seharusnya hal pokok demikian diatur di dalam UndangUndang, sama halnya dengan upaya hukum banding yang tidak dikenal pada penyelesaian perkara industrial demikian juga lebih baik mengenai upaya hukum peninjauan kembali yang ditiadakan tidak ditetapkan melalui SEMA namun dicantumkan pada Undang-Undang sehingga ada kepastian hukum. LBH KSBSI yang telah dinyatakan tidak memiliki legal standing memang sulit untuk melakukan upaya hukum selanjutnya, jika mengajukan gugatan dari awal untuk perkara yang sama maka nebis in idem, jika mengajukan peninjauan kembali akan terbentur dengan SEMA. Reytman berpendapat satu-satunya upaya hukum yang dapat dilakukan oleh LBH KSBSI adalah melakukan gugatan perlawanan terhadap pihak pengusaha, yaitu PT. Petaling Mandra Guna dalam bentuk gugatan baru menyangkut permasalahan legal standing kuasa hukum serikat pekerja yang dinyatakan tidak absah.

Kuasa hukum dari LBH KSBSI, Roida Pane memberi pernyataan akan menggugat kembali pihak perusahaan, yakni PT. Petaling Mandra Guna terkait pokok perkara pada putusan Pengadilan Hubungan Industrial pada Pengadilan Negeri Jambi perihal hak-hak pekerja yang belum terselesaikan, yaitu kekurangan upah lembur serta 
pesangon. Tercapainya suatu keadilan harus tetap diupayakan karena Hakim sama sekali tidak menyentuh apa yang menjadi pokok perkara sesuai dengan Putusan Nomor 7/G/2017/PHI.Jmb terlebih Hakim Mahkamah Agung turut menguatkan putusan Pengadilan Hubungan Industrial pada Pengadilan Negeri Jambi tersebut. Sehingga sebagai kuasa hukum, pihaknya memutuskan untuk mengajukan gugatan kembali terkait permasalahan upah lembur dan pesangon untuk karyawan PT. Petaling Mandra Guna pada perkara ini.

\section{PENUTUP}

\section{A. Kesimpulan}

Berdasarkan analisis yang telah dilakukan diatas, kemudian ditarik beberapa kesimpulan terkait permasalahan pada penelitian ini, yaitu:

a. Serikat pekerja kedudukannya sebagai kuasa hukum di Indonesia diatur pada Pasal 87 UUPPHI Nomor 2 Tahun 2004 dan Pasal 25
Ayat (1) huruf b Undang-Undang Nomor 21 Tahun 2000 tentang Serikat Pekerja. Kuasa hukum pada LBH KSBSI dalam mewakili para pekerja di PT. Petaling Mandra Guna adalah seorang advokat sekaligus seorang Ketua Koordinator Wilayah KSBSI Jambi yang menunjukkan eksistensinya sebagai anggota dan pengurus organisasi serikat pekerja KSBSI, sehingga pertimbangan Hakim pada Putusan Nomor 7/G/2017/PHI.Jmb juncto Putusan Mahkamah Agung Nomor 959 K/Pdt.Sus-PHI/2017 dapat dikatakan memutus di luar kewenangan dan kompetensi Pengadilan Hubungan Industrial. Pemutusan pada perkara dengan pertimbangan terdapatnya pelanggaran hak cipta atas nama dan logo pada kasus HKI Putusan Nomor 378-K/Pdt.Sus/HKI 2015 adalah di luar konteks, karena Hakim sama sekali tidak membahas pokok perkara melainkan justru mengabulkan eksepsi dari pihak tergugat terkait permasalahan nama dan logo SBSI yang tidak termasuk 
sebagai empat (perselisihan hak, kepentingan, pemutusan hubungan kerja dan antar serikat pekerja) perselisihan dalam hubungan industrial yang seharusnya dikesampingkan oleh Pengadilan Hubungan Industrial, bukan diterima.

Perihal kedudukan hukum atau legal standing serikat pekerja dalam mewakili para pihak ditentukan oleh dua hal berlandaskan pada UndangUndang Serikat Pekerja dan Undang-Undang Penyelesaian Perselisihan Hubungan Industrial, yaitu sudah tercatat di Dinas Tenaga Kerja dan merupakan anggota dari serikat pekerja. Setelah dua hal tersebut dipenuhi maka sebuah serikat pekerja absah kedudukannya dalam mewakili para pihak dan jelas memiliki legal standing untuk menjadi kuasa hukum dalam bertindak di Pengadilan Hubungan Industrial. Secara kelembagaan, organisasi KSBSI telah tercatat di Dinas Tenaga Kerja dengan Nomor 560.6/03/PK-F.HUKATAN

SBSI/PT-PMG/VII/2015 dan kuasa hukum pada LBH KSBSI merupakan pengurus dan anggota dari serikat pekerja KSBSI.

b. Upaya hukum yang dapat dilakukan oleh LBH KSBSI Prov. Jambi sebagai kuasa hukum setelah dinyatakan tidak mempunyai legal standing untuk mewakili para pihak pada perkara ini adalah menggugat kembali pihak PT. Petaling Mandra Guna yaitu pokok perkara perihal kekurangan upah lembur dan pesangon untuk karyawan yang tidak sesuai dibayarkan serta mengganti nama LBH KSBSI. Gugatan ulang ini dilakukan karena Hakim dalam memutus sebelumnya pada Putusan Nomor 7/G/2017/PHI.Jmb juncto Putusan Mahkamah Agung Nomor 959 K/Pdt.Sus-PHI/2017 sama sekali tidak memutus berdasarkan gugatan pada pokok perkara.

\section{B. Saran}

Pada penulisan ini, adapun saran yang diberikan adalah bagi pihak Pengadilan Hubungan Industrial sebagai badan peradilan (Judex 
factie) sebaiknya tetap berpijak kepada kewenangan dan kompetensi nya dalam memutus perkara hubungan industrial saja secara khusus sehingga tidak menimbulkan ketidakpastian hukum. Bagi pihak LBH KSBSI sebaiknya segera mengajukan upaya hukum berupa gugatan baru mengenai pokok perkara agar segera memperoleh kepastian hukum. Kemudian bagi badan legislatif diharapkan dapat mencantumkan ketentuan mengenai pembatasan upaya hukum yang dimaksud pada SEMA Nomor 3 Tahun 2018 pada UUPPHI Nomor 2 Tahun 2004 tentang Penyelesaian Perkara Hubungan Industrial sehingga diharapkan pada praktek hal tersebut benar-benar menjadi sumber hukum dan tidak hanya terbatas pada bentuk peraturan atau regelling.

\section{DAFTAR PUSTAKA}

\section{A. Buku}

Asikin, Zainal. Hukum Acara

Perdata di Indonesia. (Jakarta:

Kencana, 2015).
Harahap, M Yahya. Hukum Acara Perdata. (Jakarta: Rajawali Press, 2012).

HS, H Salim dan Erlies Seoptiana Nurbani.

Penerapan Teori Hukum pada Penelitian Tesis dan Disertasi. (Jakarta: PT Raja Grafindo, 2013).

HS, H Salim. Perkembangan Teori dalam Ilmu Hukum. (Jakarta: PT Raja Grafindo Persada, 2010).

Husni, Lalu. Hukum

Ketenagakerjaan

Indonesia. Cetakan ke-4. (Jakarta: Raja Grafindo Persada, 2003).

Marzuki, Peter Mahmud. Penelitian Hukum.

Cetakan ke-8. (Jakarta: Kencana Prenada Media Group, 2013).

Mertokusumo, Sudikno.

Mengenal Hukum Suatu Pengantar. (Yogyakarta: Liberty, 1999).

Sutantio, Retnowulan dan Iskandar 
Volume 17, No. 1, Juni 2019

Oeripkartawinata. Hukum

Acara Perdata dalam

Teori dan Praktek.

(Bandung: CV Mandar

Maju, 2009).

B. Peraturan

Perundang-

undangan

Indonesia. Undang-Undang

Dasar Negara Republik

Indonesia Tahun 1945.

Indonesia. Undang-Undang

Republik Indonesia

Nomor 21 Tahun 2000

tentang Serikat Buruh

(Lembaran Negara

Republik Indonesia Tahun

2000 Nomor 131,

Tambahan Lembaran

Negara Republik

Indonesia Nomor 3889).

Indonesia. Undang-Undang

Republik Indonesia

Nomor 13 Tahun 2003

tentang Ketenagakerjaan

(Lembaran

Negara

Republik Indonesia Tahun

2003 Nomor 39;

Tambahan Lembaran
Negara

Republik

Indonesia Nomor 4279).

Indonesia. Undang-Undang

Republik Indonesia

Nomor 2 Tahun 2004

tentang Penyelesaian

Perselisihan Industrial

(Lembaran Negara

Republik Indonesia Tahun

2004 Nomor 6;

Tambahan Lembaran

Negara Republik

Indonesia Nomor 4356).

Indonesia. Undang-Undang

Republik Indonesia

Nomor 18 Tahun 2003

tentang Advokat

(Lembaran Negara

Republik Indinesia

Tahun 2003 Nomor 49;

Tambahan Lembaran

Negara Republik

Indonesia Nomor

4288. Indonesia.

Undang-Undang

Republik Indonesia

Nomor 12 Tahun 2011

tentang Pembentukan

Peraturan Perundang- 
Volume 17, No. 1, Juni 2019

$\begin{array}{lr}\text { Undangan } & \text { (Lembaran } \\ \text { Negara } & \text { Republik } \\ \text { Indinesia } & \text { Tahun 20011 } \\ \text { Nomor 82; } & \text { Tambahan } \\ \text { Lembaran } & \text { Negara } \\ \text { Republik } & \text { Indonesia }\end{array}$

Nomor 5234.

\section{Kamus}

Garner, Bryan A. Black's Law Dictionary. (St. Paul, Minn: West Group, 2009). 